\title{
Preformed and regenerated phosphate in ocean general circulation models: can right total concentrations be wrong?
}

\author{
O. Duteil ${ }^{1}$, W. Koeve ${ }^{1}$, A. Oschlies ${ }^{1}$, O. Aumont ${ }^{2}$, D. Bianchi ${ }^{3}$, L. Bopp ${ }^{4}$, E. Galbraith ${ }^{5}$, R. Matear ${ }^{6}$, J. K. Moore ${ }^{7}$, \\ J. L. Sarmiento ${ }^{3}$, and J. Segschneider ${ }^{8}$ \\ ${ }^{1}$ GEOMAR, Helmholtz-Zentrum für Ozeanforschung Kiel, Düsternbrooker Weg 20, 24105 Kiel, Germany \\ ${ }^{2}$ Centre IRD de Bretagne - BP70 - 29280 Plouzane, France \\ ${ }^{3}$ AOS Program, Princeton University, Forrestal Campus, P.O. Box CN710, Princeton, NJ 08544-0710, USA \\ ${ }^{4}$ Laboratoire des Sciences du Climat et de l'Environnement, Orme des Merisiers, CE Saclay, 91191 Gif sur Yvette, France \\ ${ }^{5}$ Department of Earth and Planetary Science, McGill University, Montreal, QC, Canada \\ ${ }^{6}$ CSIRO Marine and Atmosphere Research, Hobart, TAS, Australia \\ ${ }^{7}$ Department of Earth System Science, University of California, Irvine, CA 92697, USA \\ ${ }^{8}$ Max-Planck-Institut für Meteorologie, Bundesstrasse 53, 20146 Hamburg, Germany
}

Correspondence to: O. Duteil (oduteil@geomar.de)

Received: 6 December 2011 - Published in Biogeosciences Discuss.: 21 December 2011

Revised: 10 April 2012 - Accepted: 24 April 2012 - Published: 23 May 2012

\begin{abstract}
Phosphate distributions simulated by seven stateof-the-art biogeochemical ocean circulation models are evaluated against observations of global ocean nutrient distributions. The biogeochemical models exhibit different structural complexities, ranging from simple nutrient-restoring to multi-nutrient NPZD type models. We evaluate the simulations using the observed volume distribution of phosphate. The errors in these simulated volume class distributions are significantly larger when preformed phosphate (or regenerated phosphate) rather than total phosphate is considered. Our analysis reveals that models can achieve similarly good fits to observed total phosphate distributions for a very different partitioning into preformed and regenerated nutrient components. This has implications for the strength and potential climate sensitivity of the simulated biological carbon pump. We suggest complementing the use of total nutrient distributions for assessing model skill by an evaluation of the respective preformed and regenerated nutrient components.
\end{abstract}

\section{Introduction}

The distribution of phosphate $\left(\mathrm{PO}_{4}\right)$ in the ocean is controlled by a wide range of processes. In the absence of major external sources, internal processes are the main drivers, namely the physical circulation and the marine biology. $\mathrm{PO}_{4}$ is incorporated into organic matter by photosynthetic phytoplankton in the euphotic zone. A fraction of this organic matter escapes recycling in the surface layer and is exported into the ocean interior. Remineralisation of organic matter by bacteria and zooplankton releases nutrients such as $\mathrm{PO}_{4}$ and consumes oxygen. This phosphate is called "regenerated phosphate". The remaining phosphate is the biotically unutilized surface phosphate, which enters the ocean by subduction during water mass formation, and is called "preformed phosphate". According to observational estimates, the preformed phosphate makes up for about $60 \%$ of the global ocean's phosphate inventory, whereas regenerated phosphate derived from remineralisation of organic matter makes up for the remaining $40 \%$ (Ito and Follows, 2005).

Patterns of $\mathrm{PO}_{4}$ concentrations as well as the partitioning into preformed and regenerated components are sensitive to ocean circulation, export production and remineralisation length scale. For example, a more active biology increases the transfer of phosphate from surface to intermediate depths by remineralisation, depleting surface nutrients. Consequently, the amount of phosphate subducted at high latitudes, i.e. the preformed phosphate, decreases as well. As another example, a more vigorous overturning results in higher supply rates of nutrients from the deep ocean to the 
Table 1. General description of the models used in this study.

\begin{tabular}{|c|c|c|c|c|c|c|c|}
\hline Model & OPA-PISCES & $\begin{array}{l}\text { MPIOM- } \\
\text { HAMOCC }\end{array}$ & CCSM3-BEC & UVIC & $\begin{array}{l}\text { om1p7- } \\
\text { BLINGv0 }\end{array}$ & CSIRO & MOM-P2A \\
\hline Resolution & $\begin{array}{l}0.5 \text { (eq.) to } \\
2 \times 2\end{array}$ & $\begin{array}{l}0.5 \text { (NA) } \\
1.5 \times 1.5\end{array} \quad$ to & $\begin{array}{l}0.9 \text { (eq.) to } \\
2 \times 3.6\end{array}$ & $1.8 \times 3.6$ & $\begin{array}{l}0.6 \text { (eq.) to } \\
2 \times 3\end{array}$ & $3.2 \times 5.6$ & $3.75 \times 4$ \\
\hline Levels & 31 & 40 & 25 & 19 & 28 & 21 & 24 \\
\hline Mixed Layer & TKE & TKE & KPP & - & KPP & - & - \\
\hline Wind stress & ERS & NCEP-NCAR & NCEP-NCAR & NCEP-NCAR & CORE & $\begin{array}{l}\text { Previous cou- } \\
\text { pled exp. }\end{array}$ & ECMWF \\
\hline Biology & NPZD & NPZD & NPZD & NPZD & $\mathrm{N}$ & $\mathrm{N}$ & OCMIP (N) \\
\hline Boxes & $\begin{array}{l}24 \\
2 \text { phy., } \\
2 \text { zoo., } \\
\mathrm{NO}_{3}, \\
\mathrm{PO}_{4}, \\
\text { Detritus, } \\
\mathrm{O}_{2}, \\
\text { Carb., } \\
\text { Iron, } \\
\text { Sil. }\end{array}$ & $\begin{array}{l}18 \\
1 \text { phy.*, } \\
1 \text { zoo., } \\
\mathrm{NO}_{3}, \\
\mathrm{PO}_{4}, \\
\text { Detritus, } \\
\mathrm{O}_{2}, \\
\text { Carb., } \\
\text { Iron, } \\
\text { Sil }\end{array}$ & $\begin{array}{l}18 \\
4 \text { phy., } \\
1 \text { zoo., } \\
\mathrm{NO}_{3}, \\
\mathrm{PO}_{4}, \\
\text { Detritus, } \\
\mathrm{O}_{2}, \\
\text { Carb., } \\
\text { Iron, } \\
\text { Sil. }\end{array}$ & $\begin{array}{l}9 \\
2 \text { phy., } \\
1 \text { zoo., } \\
\mathrm{NO}_{3}, \\
\mathrm{PO}_{4}, \\
\text { Detritus, } \\
\mathrm{O}_{2}, \\
\text { DIC, } \\
\text { TALK }\end{array}$ & $\begin{array}{l}4 \\
\text { implicit PZD, } \\
\mathrm{PO}_{4}, \\
\mathrm{DOP}, \\
\mathrm{O}_{2}, \\
\text { Iron }\end{array}$ & $\begin{array}{l}4 \\
\text { implicit PZD, } \\
\mathrm{PO}_{4}, \\
\mathrm{O}_{2}, \\
\text { DIC, } \\
\text { TALK }\end{array}$ & $\begin{array}{l}5 \\
\text { implicit PZD, } \\
\mathrm{PO}_{4}, \\
\mathrm{DOP}, \\
\mathrm{O}_{2}, \\
\text { DIC, } \\
\text { TALK }\end{array}$ \\
\hline Ref. & $\begin{array}{l}\text { Aumont and } \\
\text { Bopp } \\
(2006)\end{array}$ & $\begin{array}{l}\text { Maier-Reimer } \\
\text { et al. (2005) }\end{array}$ & $\begin{array}{l}\text { Krishnamurty } \\
\text { et al. (2009) }\end{array}$ & $\begin{array}{l}\text { Oschlies } \\
\text { et al. (2008) }\end{array}$ & $\begin{array}{l}\text { Galbraith } \\
\text { et al. }(2010)\end{array}$ & $\begin{array}{l}\text { Matear and } \\
\text { Hirst } \\
(2003)\end{array}$ & $\begin{array}{l}\text { Gnanadesikan } \\
\text { et al. (2004) }\end{array}$ \\
\hline
\end{tabular}

* Implicitely partionned into diatoms and coccolitophores depending on available silicate.

euphotic zone, which will increase surface nutrient levels. Thereby, the preformed $\mathrm{PO}_{4}$ pool increases whereas the regenerated $\mathrm{PO}_{4}$ pool decreases. A model that correctly simulates biogeochemical and physical processes should represent not only the total phosphate distribution, but also reproduce its preformed and regenerated pools in a realistic way.

The global $\mathrm{PO}_{4}$ distribution is characterised by generally low $\mathrm{PO}_{4}$ values in surface waters and high concentrations in the deep ocean, with maximum concentrations often found in intermediate waters associated with low oxygen concentrations. This picture is usually well reproduced by ocean general circulation models, as depicted by model intercomparison studies (Najjar et al., 2007), which have been conducted for instance in the context of the Ocean Carbon-cycle Model Intercomparison Project (OCMIP). OCMIP compared models with a simplistic representation of marine biogeochemistry, i.e. restoring of nutrients at the sea surface and no explicit representation of phytoplankton. More complex biological models were used in the Coupled Carbon Cycle Climate Model Intercomparison Project (C4MIP) that focussed on the coupling of climate and the carbon cycle (Friedlingstein et al., 2006). Schneider et al. (2008) assessed surface $\mathrm{PO}_{4}$, export and primary production simulated by three C4MIP models. Carbon fluxes at the ocean atmosphere interface have been assessed using a suite of fully coupled climate models (Roy et al., 2011).

All these studies focused on total nutrient concentrations. The partitioning between regenerated and preformed pools has, to our knowledge, not been considered in previous model intercomparison studies. Previous studies aimed at a better understanding of the interactions of climate and biogeochemistry have found preformed $\mathrm{PO}_{4}$ to be an excellent indicator of atmospheric $p \mathrm{CO}_{2}$, with a positive correlation between the atmospheric $\mathrm{CO}_{2}$ levels and the relative amount of preformed phosphate in the ocean interior (Ito and Follows, 2005; Marinov et al., 2008). By contrast, the total surface nutrient inventory is not necessarily correlated with atmospheric $p \mathrm{CO}_{2}$ and oceanic circulation changes.

The objective of this study is to illustrate that additional information can be gained by explicitly considering preformed and regenerated nutrients pools in the evaluation of biogeochemical models. We here exploit 7 state-of-the-art coupled biogeochemical-circulation models to demonstrate how the separation of the phosphate into preformed and regenerate concentrations can improve the assessment of the simulations. 


\section{Datasets}

Seven global biogeochemical-circulation models used in previous studies are considered here (see Table 1 for details): OPA-PISCES (Aumont and Bopp, 2006), MPIOMHAMOCC (Maier-Reimer, 1993; Maier-Reimer et al., 2005), CCSM3-BEC (Krishnamurthy et al., 2009), UVIC2.8 (Oschlies et al., 2008), om1p7-BLINGv0 (Galbraith et al., 2010), CSIRO (Matear and Hirst, 2003), MOM P2A (Gnanadesikan et al., 2004).

Given that the partitioning into preformed and regenerated nutrients is likely sensitive to the models' parameter choices and the forcing used, the behaviour of the models shown here should not be extrapolated to other model configurations.

All models were forced by prescribed atmospheric conditions in an attempt to obtain realistic pre-industrial circulation fields. The pelagic ecosystem part of the biogeochemical models ranges from relatively simple nutrient restoring-type models (CSIRO, MOM P2A) to intermediate complexity nutrient-phytoplankton-zooplankton-detritus (NPZD) (UVIC2.8, om1p7-BLINGv0) and more complex models with multiple plankton functional types (OPAPISCES, MPIOM-HAMOCC, CCSM3-BEC). All models were integrated for at least $2000 \mathrm{yr}$ to reach a steady state quasi-equilibrium. Annual mean output from these models is compared against objectively analysed annual means of the World Ocean Atlas (WOA) 2005 (Garcia et al., 2006a,b).

When using WOA as the ground truth against which we compare the different models, one has to keep in mind that there are inherent errors in this annual-mean composite of observations, specifically due to measurement errors, seasonal and regional sampling biases and interpolation effects. In particular, the scarcity of observations during winter time at high latitudes, especially in the North Atlantic and the Southern Ocean, might lead to a bias in the annual mean climatology of the upper ocean towards summer. In the deep ocean, however, phosphate and oxygen concentrations as well as temperature and salinity show little to no seasonal variations (e.g. Conkright et al., 2000). Here, seasonal bias in sampling is hence of minor importance. Our analysis considers concentration distributions over the entire water column, of which the upper ocean represents only a relative small fraction. For the objective of this study, potential upper ocean sampling biases are therefore assumed to have only a very small effect. Prior to analysis, all model output fields were regridded onto the 33 levels $1 \times 1$ degree WOA grid.

The distribution of the regenerated phosphate can be expressed in a general way as $\mathrm{P}_{\text {Regenerated }}=\sum \mathrm{P}_{\text {Regenerated (Oxidant) }}$ where possible oxidants are oxygen, nitrate, manganese oxides, iron oxides, sulfate and eventually $\mathrm{CO}_{2}$. Organic matter remineralisation using oxygen occurs everywhere in the ocean, except in places where oxygen is essentially depleted (suboxic regions). In this case, $\mathrm{NO}_{3}$ and $\mathrm{NO}_{2}$ may be used as electron acceptors for the oxidation of organic matter. The global importance of oxygen vs. $\mathrm{NO}_{3}$ as electron acceptors can roughly be quantified from comparing current estimates of denitrification and the global export production in the ocean interior. The estimated loss of $\mathrm{N}$ is about $100 \mathrm{Tg} \mathrm{N}$ $\mathrm{yr}^{-1}$ (Codispoti et al., 2001), which represents about $7 \mathrm{Tmol}$ $\mathrm{C} \mathrm{yr}^{-1}\left(0.08 \mathrm{Gt} \mathrm{C} \mathrm{yr}^{-1}\right.$ equivalents) as roughly 1 mole $\mathrm{NO}_{3}$ is consumed during the oxidation of 1 mole carbon (Koeve and Kähler, 2010). The export flux is estimated to be about $10 \mathrm{Gt} \mathrm{C} \mathrm{yr}^{-1}$ (e.g., Schlitzer, 2002). The amount of phosphate regenerated under suboxic conditions is equal to the ratio between these two quantities and accounts for about 1 percent of the aerobically remineralized phosphate. Remineralization by other compounds (sulfate, some metals) occurs only in enclosed seas (Black Sea, Baltic, some fjords) and in sediments in shelf and coastal waters. It may locally be important relative to aerobic demineralization, but in the open ocean's pelagic realm investigated here is not considered to play a significant role.

For the main analysis of this paper, we assume that $\mathrm{P}_{\text {Regenerated }}$ can be approximated by $\mathrm{P}_{\text {Regenerated }}\left(\mathrm{O}_{2}\right)$. Impacts of denitrification, i.e. $\mathrm{P}_{\text {Regenerated }}\left(\mathrm{NO}_{3}\right)$, are estimated for models that include both a nitrogen and phosphorus cycle (see Appendix). However, due to the limited validity of this estimate and the relatively small impact of phosphorus regeneration by denitrification on our results (see Fig. A1), we focus on aerobic processes in the main part of this study. Regenerated phosphate is computed by multiplying the Apparent Oxygen Utilisation (AOU) with the oxidation ratio $R_{\mathrm{P}:-\mathrm{O}_{2}}$

$\mathrm{P}_{\text {Regenerated }}=R_{\mathrm{P}:-\mathrm{O}_{2}} \mathrm{AOU}$

Apparent Oxygen Utilisation (AOU) evaluates integral oxygen consumption by biological activity and is computed as the difference between the oxygen saturation concentration, which depends on thermohaline properties (Weiss, 1970), and the actually observed oxygen concentration. The $R_{\mathrm{P}:-\mathrm{O}_{2}}$ ratio is assumed to be a fixed and constant stoichiometric ratio between phosphate production and oxygen consumption.

This ratio has been set to 1/172 in OPA-PISCES, MPIOMHAMOCC, 1/170 in CCSM3-BEC, CSIRO, MOM P2A, UVIC2.8 and $1 / 150$ in om1p7-BLINGv0. We use these model values when analyzing the respective models outputs. A common $R_{\mathrm{P}:-\mathrm{O}_{2}}$ value of $1 / 170$ is used for the analysis of WOA data independently of the value considered in the different models. Indeed, generally accepted values derived from ocean data are close to 1/170 (Takahashi et al., 1985; Kortzinger et al., 2001; Anderson and Sarmiento, 1994; $\mathrm{Li}$ et al., 2000). It has been shown that this ratio is nearly uniform with location and depth. Using TTO/NAS and GEOSECS data in Atlantic and Indian Ocean, Takahashi et al. (1985) found no evidence for a significant difference between the estimate ratios of oxygen consumption to phosphate release for thermocline waters in the Atlantic and Indian Oceans. Similar $-\mathrm{O}_{2} / \mathrm{P}$ values have also been observed in the deep Pacific (about 2.7 to $3.5 \mathrm{~km}$ deep), deep Indian 


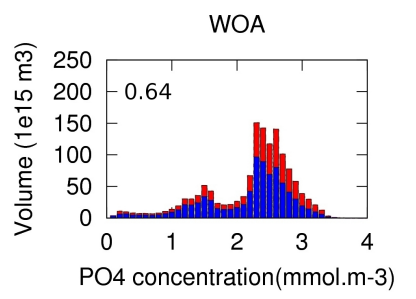

MPIOM-HAMOCC

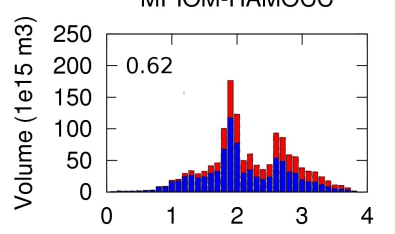

PO4 concentration(mmol.m-3)

UVIC

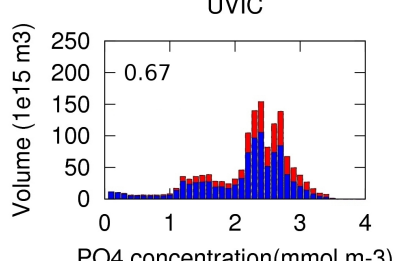

$\mathrm{PO} 4$ concentration(mmol.m-3)

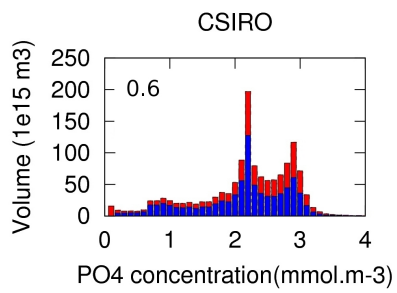

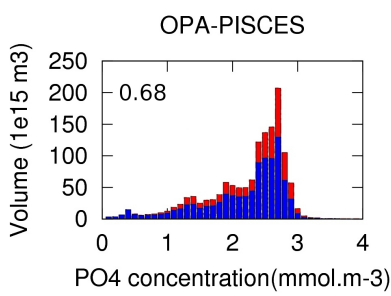

CCSM3-BEC

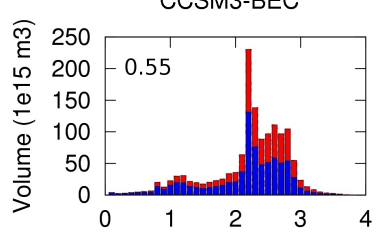

PO4 concentration(mmol.m-3)

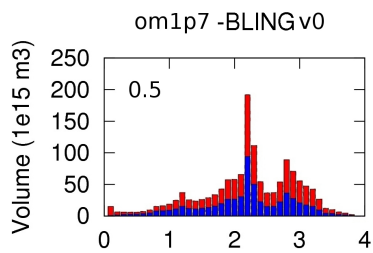

PO4 concentration(mmol.m-3)

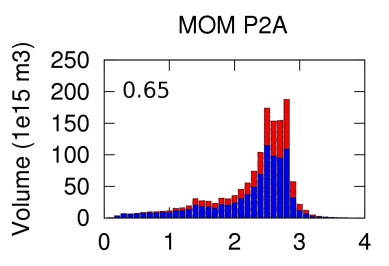

PO4 concentration(mmol.m-3)

Fig. 1. Total phosphate $\left(\mathrm{mmol} \mathrm{m}^{-3}\right)$ volume distribution in WOA, OPA-PISCES, MPIOM-HAMOCC, CCSM3-BEC, UVIC2.8, om1p7-BLINGv0, CSIRO, MOM P2A for bin sizes of $0.1 \mathrm{mmol} \mathrm{m}^{-3}$. The numbers indicate the global mean fraction of preformed over total phosphate. The blue (red) bars indicate the mean fraction of preformed (regenerated) phosphate in each bin.

Ocean (about $3.5 \mathrm{~km}$ deep), the Red Sea, and the Norwegian Sea (Broecker et al., 1985).

Preformed phosphate is computed as the difference between total and regenerated phosphates

$\mathrm{P}_{\text {Preformed }}=\mathrm{P}-\mathrm{P}_{\text {Regenerated }}$

With a piston velocity for oxygen of several meters per day, the timescale needed for the oxygen concentrations in the ocean's surface mixed layer, typically several tens of meters thick, to equilibrate with the atmospheric can reach a few weeks (e.g. Broecker and Peng, 1982). We note that, despite the relative rapidity of the $\mathrm{O}_{2}$ air-sea gas exchange (rapid when compared with one to two orders of magnitude longer equilibration timescales for the strongly buffered $\mathrm{CO}_{2}$ ), equilibrium of surface waters with atmospheric oxygen is actually not perfect and may be prevented by physical processes, such as surface heat loss or entrainment of oxygen depleted
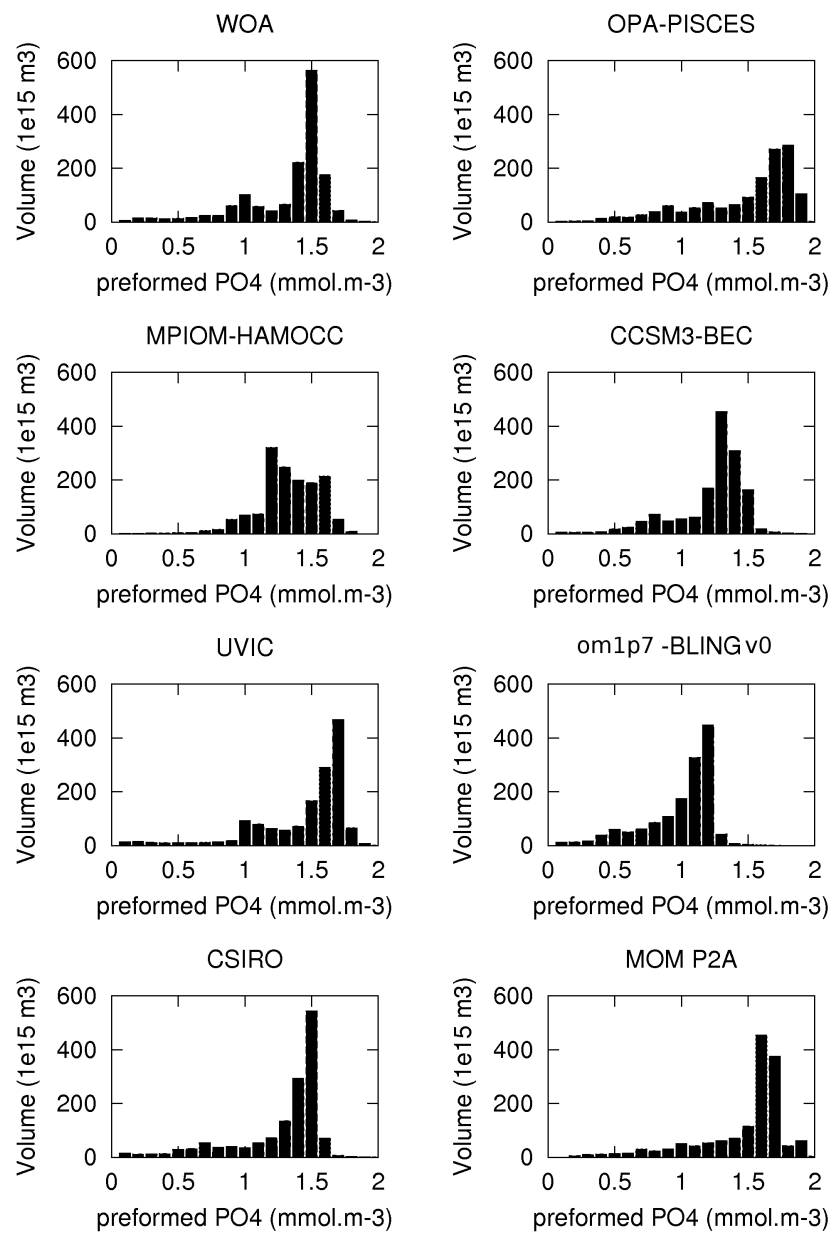

Fig. 2. Preformed phosphate $\left(\mathrm{mmol} \mathrm{m}^{-3}\right)$ volume distribution in WOA, OPA-PISCES, MPIOM-HAMOCC, CCSM3-BEC, UVIC2.8, om1p7-BLINGv0, CSIRO, MOM P2A.

deep water. Computed AOU might be higher than the true oxygen utilisation, especially for waters with high-latitude outcrop regions (Ito et al., 2004). While the processes controlling the saturation state of oxygen in the surface waters are not well constrained by available observations, we pragmatically use the AOU metric in this study. We acknowledge the limitation of the AOU approach, and we assume that all our datasets, model outputs as well as observations, are affected similarly.

\section{Means and volume distributions}

In WOA, total $\mathrm{PO}_{4}$ concentrations range from close to 0 to maximum values of $4.9 \mathrm{mmol} \mathrm{m}^{-3}$, with only very small parts of the global ocean volume exhibiting concentrations greater than $3.5 \mathrm{mmol} \mathrm{m}^{-3}$ (Fig. 1). The global mean value is $2.26 \mathrm{mmol} \mathrm{m}^{-3}$. The volume associated with concentrations lower than $1 \mathrm{mmol} \mathrm{m}^{-3}$ is also small and represents only $5 \%$ of the ocean volume. This low concentrations range 
a
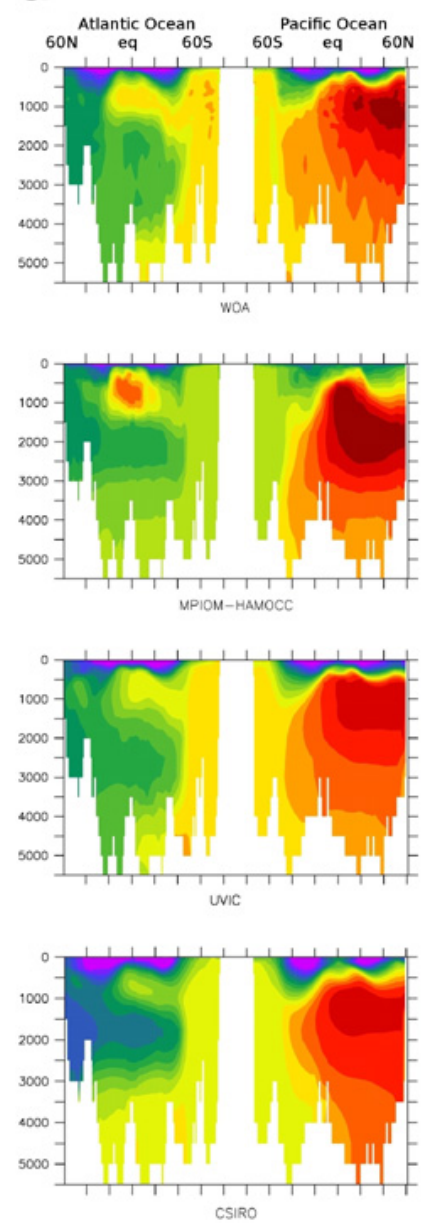

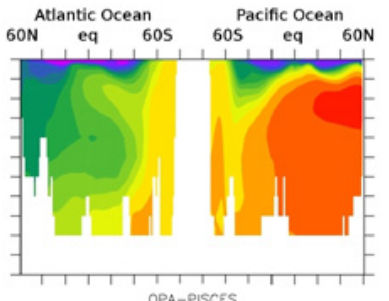

OPA-PISCES

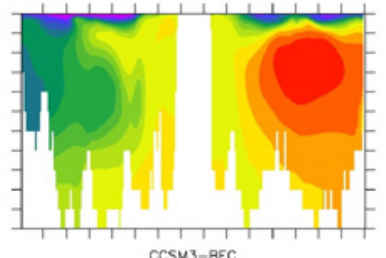

$\cos { }^{3-\mathrm{BEC}}$
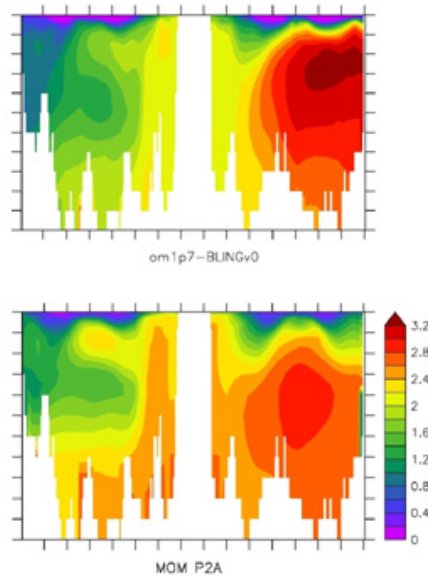

b
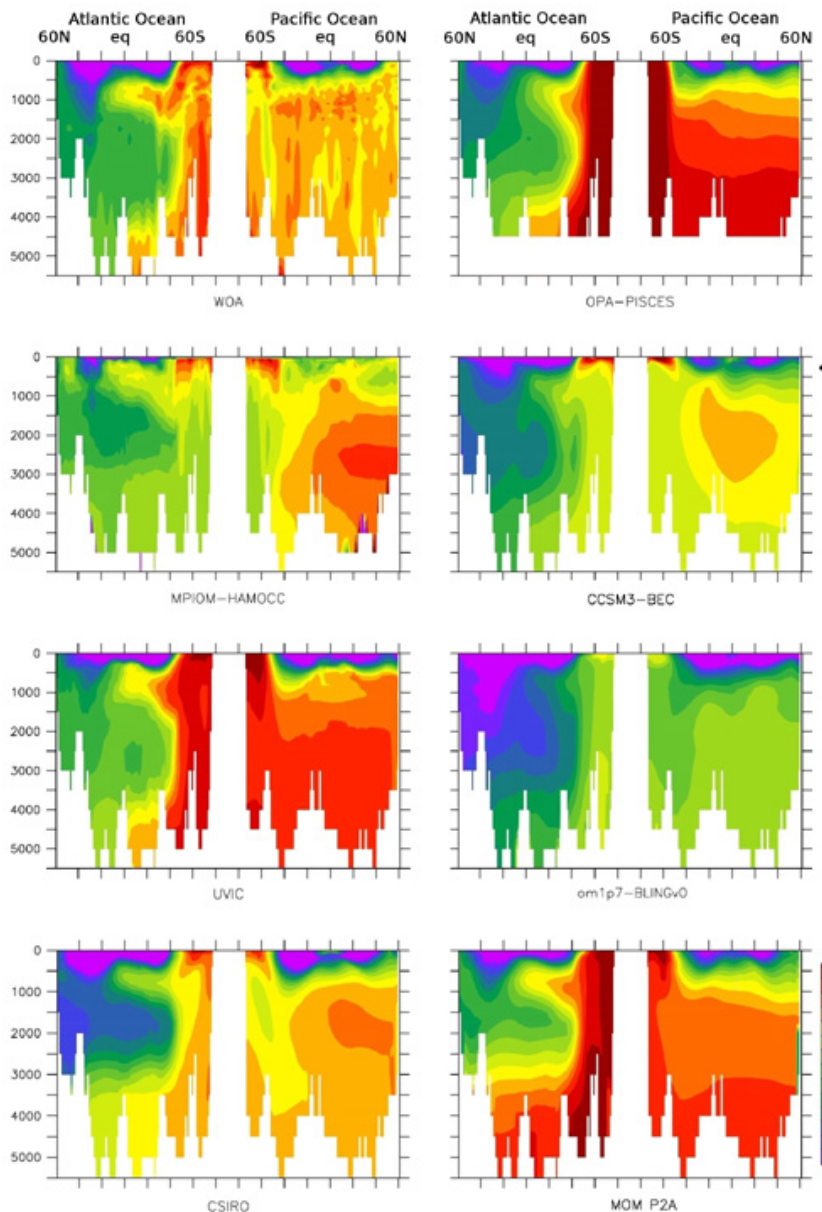

Fig. 3. Total (a) and preformed (b) phosphate concentrations $\left(\mathrm{mmol} \mathrm{m}^{-3}\right)$ along an Atlantic meridional section $\left(30^{\circ} \mathrm{W}\right)$ and a Pacific meridional section $\left(150^{\circ} \mathrm{W}\right)$ in different datasets: WOA, OPA-PISCES, MPIOM-HAMOCC, CCSM3-BEC, UVIC2.8, om1p7-BLINGv0, CSIRO, MOM P2A.

corresponds to the surface layer and the upper thermocline (Fig. 3a,b). The total oceanic phosphate pool is composed by $64 \%$ of preformed and $36 \%$ of regenerated $\mathrm{PO}_{4}$.

The observed (WOA) total phosphate volume distribution is bimodal (Fig. 1). A first mode is characterised by concentrations ranging from 1 to $1.8 \mathrm{mmol} \mathrm{m}^{-3}$, with an associated volume of $20 \%$ of the total ocean. This first mode corresponds mainly to Atlantic waters (Fig. 3), which are characterised by low phosphate values (around $1 \mathrm{mmol} \mathrm{m}^{-3}$ ) in northern subduction regions, intermediate values $\left(1.5 \mathrm{mmol} \mathrm{m}^{-3}\right)$ in tropical regions and large values (above $2 \mathrm{mmol} \mathrm{m}^{-3}$ ) in the Southern Atlantic. Subduction regions are characterised by a high fraction $(0.75)$ of preformed over total phosphate, as the sinking water mass is young and thus little biological activity occurred since its last contact with the atmosphere. This fraction is much lower in the tropical regions of the Atlantic, where biological production is high and subsurface waters are older. Preformed phosphate is low in the northern high latitude region $\left(0.8 \mathrm{mmol} \mathrm{m}^{-3}\right)$, high in the Southern Atlantic (above $1.3 \mathrm{mmol} \mathrm{m}^{-3}$ ) and intermediate in tropical waters $\left(1 \mathrm{mmol} \mathrm{m}^{-3}\right)$, where mixing occurs between waters of northern and southern origin.

The second mode of the total $\mathrm{PO}_{4}$ volume distribution (Fig. 1, WOA) ranges from 2.2 to $3.5 \mathrm{mmol} \mathrm{m}^{-3}$ and represents $70 \%$ of the ocean volume. This range of concentrations is typical for subsurface waters of the Southern Ocean, Indian and Pacific Ocean. Phosphate concentrations increase when water gets older, e.g., from the Southern Ocean $\left(2.2 \mathrm{mmol} \mathrm{m}^{-3}\right)$ towards the North Pacific, where values reach $3.0 \mathrm{mmol} \mathrm{m}^{-3}$ at intermediate depths, as seen in Fig. 3. Preformed phosphate concentrations are relatively constant in the Pacific with values of 1.4 to $1.6 \mathrm{mmol} \mathrm{m}^{-3}$ (Fig. 3b), because in contrast to the Atlantic Ocean, deep waters of the Pacific originate exclusively from the Southern Ocean. In contrast, the ratio of preformed over total phosphate decreases from the Southern Ocean $(0.75)$ northwards 
and reaches minimum values of 0.5 in the North Pacific, where regenerated $\mathrm{PO}_{4}$ and total $\mathrm{PO}_{4}$ concentrations are highest along the Pacific transect.

Global mean phosphate concentrations are similar between observations and all the studied models. Values range from $2.17 \mathrm{mmol} \mathrm{m}^{-3}$ (MPIOM-HAMOCC) to 2.35 (MOM P2A). This similarity is not surprising, since all models were initialised with phosphate fields derived from WOA. Differences reflect to a large extent the different topographies and resolution used in the different models. In order to quantify differences in the $\mathrm{PO}_{4}$ distribution between models and data, we computed a "Volume Class Error", which is the percentage of water simulated in the wrong concentration class compared to the WOA.

$\left.\mathrm{VCE}=\left(\sum_{i} \mid V_{\mathrm{PO}_{4}(i)_{\text {model }}}-V_{\mathrm{PO}_{4}(i)}\right)_{\mathrm{WOA}} \mid\right) /\left(2 \cdot V_{\text {ocean }}\right)$

where $V_{\mathrm{PO}_{4}(\mathrm{i})}$ is the volume of water for a given modeled or observed phosphate concentration class $i$ and $V_{\text {ocean }}$ is the total volume of the ocean.

When measured in terms of total phosphate concentration classes of $0.1 \mathrm{mmol} \mathrm{m}^{-3}$ width (Fig. 1), for our set of models the volume class error varies from $9 \%$ for the UVIC2.8 model to $32 \%$ in the MPIOM-HAMOCC model, with OPA-PISCES (19\%), CCSM3-BEC (20\%) and MOM P2A ( $21 \%)$, om1p7-BLINGv0 (31\%), CSIRO (31\%), displaying intermediate model-data differences (Fig. 1).

The partitioning into preformed and regenerated phosphate displays large variations among the different models. In the om1p7-BLINGv0 model, which assumes $R_{\mathrm{P}:-\mathrm{O}_{2}}=$ $1 / 150$, the global ratio of preformed over total is only 0.5 , indicating a larger share of regenerated phosphate and hence a more intensive biological carbon pump comparing to the physical one. The oceanic phosphate field simulated by the OPA-PISCES model is however determined to a larger extent by circulation-driven preformed phosphate, with a global ratio of preformed-to-total phosphate of 0.68 . Preformedto-total phosphate ratios of other models lie between these two extremes (om1p7-BLINGv0: 0.5, CCSM3-BEC: 0.55; CSIRO: 0.6, MPIOM-HAMOCC: 0.62, WOA: 0.64, MOM P2A: 0.65, UVIC2.8: 0.67, OPA-PISCES: 0.68 ) and are all relatively close to the WOA ratio of 0.64 .

The "Volume Class Error" computed for the preformed pool distribution (Fig. 2) spans from $17 \%$ for the CSIRO model to $69 \%$ for om1p7-BLINGv0 (35\% MPIOMHAMOCC, $44 \%$ UVIC2.8, $47 \%$ CCSM3-BEC, $48 \%$ OPAPISCES, $49 \%$ MOM P2A). For all models but CSIRO, the error in preformed phosphate is greater than the error in the total phosphate. It demonstrates that the mechanisms, whether dynamical or biological, responsible for the setting of preformed phosphate concentrations are not as well represented as suggested by just the total phosphate concentrations. The good performance of CSIRO might be due to the use of flux adjustments at ocean surface and particularly in the Southern Ocean (Matear and Hirst, 2003), leading to a more realistic winter mixed layer, convection depth and subduction of water in the Southern Ocean.

\section{Water masses}

In order to better understand what causes the differences in the $\mathrm{PO}_{4}$ distributions, we analyse the models' representations of the main water masses in the Atlantic and the Pacific Ocean.

Deep waters of the Atlantic Ocean are formed at high latitudes, both in the north (North Atlantic Deep Water: NADW) and in the Southern Ocean (Antarctic Bottom Water: $\mathrm{AABW}$ ). In the North Atlantic interior (below $500 \mathrm{~m}$ and from 40 to $60^{\circ} \mathrm{N}$ ) (Fig. 3), concentrations of total phosphate range from around 0.8 (CSIRO) to 1.5 (MOM P2A) $\mathrm{mmol} \mathrm{m}^{-3}$ and concentrations of preformed phosphate from 0.4 (om1p7-BLINGv0), 0.6 (CSIRO) to $1 \mathrm{mmol} \mathrm{m}^{-3}$ (MOM P2A). Some models display preformed values in the NADW substantially lower than the WOA preformed $\mathrm{PO}_{4}$ of about $0.8 \mathrm{mmol} \mathrm{m}^{-3}$ (CCSM3-BEC, om1p7-BLINGv0, CSIRO).This apparent depletion of nutrients in the highlatitude water mass formation areas could be caused by too intense biological activity or too sluggish circulation.

Simulated total $\mathrm{PO}_{4}$ concentrations in the Southern Ocean ( 80 to $60^{\circ} \mathrm{S}$ ) show relatively small variations among the different models ranging from around 1.9 (MPIOM-HAMOCC) to $2.5 \mathrm{mmol} \mathrm{m}^{-3}$ (MOM P2A) (Fig. 3a). However, the partitioning into preformed and regenerated phosphate varies substantially among the different models (Fig. 3b). Simulated preformed phosphate concentrations in the Southern Ocean range from around 1.1 (MPIOM-HAMOCC) to $1.8 \mathrm{mmol} \mathrm{m}^{-3}$ (OPA-PISCES). For relatively simple nutrient-restoring biogeochemistry models it has been shown that low preformed Southern Ocean phosphate concentrations can be related to sluggish circulation and weak overturning (Marinov et al., 2008). Significant differences between the end member values of preformed $\mathrm{PO}_{4}$ in the different models suggest that an identical concentration of preformed $\mathrm{PO}_{4}$ is achieved through a different combination of NADW and AABW in the deep ocean, which is likely to have biogeochemical implications, e.g. on oxygen concentration.

In all of the models investigated, the simulated tongue of NADW with low preformed phosphate concentrations occupies a depth range of about $2000-3000 \mathrm{~m}$ and is thinner than in the World Ocean Atlas (Fig. 3b). AABW, generally rich in preformed nutrients, extends northward throughout the Atlantic in most models, whereas it is more mixed with NADW in observations in tropical regions. A tongue of relatively high phosphate concentrations is seen at intermediate depths in the tropical Central Atlantic Ocean. This feature is due both to the subduction of Antartic Intermediate Water, characterised by high preformed nutrient values, and high remineralisation in the tropics. In some models 

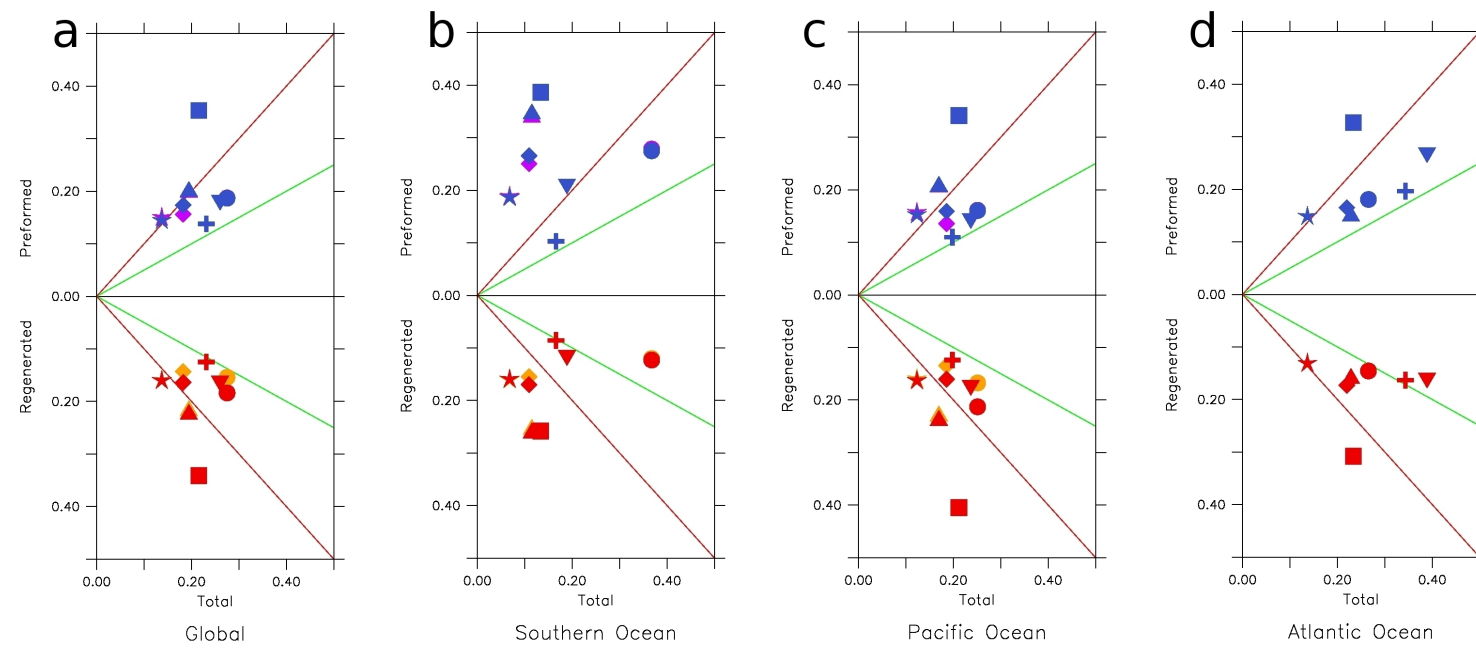

$\triangle$ OPA - PISCES

- MPIOM - HAMOCC

- CCSM3 - BEC

$\star$ UVIC

- om1p7 - BLINGv0

+ CSIRO

$\checkmark$ MOM P2A

Fig. 4. Absolute misfits $\left(\mathrm{mmol} \mathrm{m}^{-3}\right.$ ) for regenerated, preformed (ordinate) and total phosphate (abscissa) in (a) global, (b) Southern Ocean, (c) Pacific and (d) Atlantic Ocean. In a model where no compensation between preformed and regenerated pool exists, one should expect that the total phosphate misfit is the sum of the preformed and regenerated misfits. In this case, and considering that total phosphate misfits are, at each location, caused by either the preformed or regenerated pool, with equal amounts of preformed and regenerated phosphate misfits, the models should be located along the green lines. Several models present lower total misfits than the sum of preformed and regenerated misfits. This is particularly the case for models reaching the red line (misfits in preformed or regenerated are at least equal to the total misfit). Yellow/purple symbols visible for the models MPIOM-HAMMOCC and CCSM3-BEC include a correction for the estimated contribution of denitrification to the regenerated phosphate pool (see Appendix).

(MPIOM-HAMOCC, MOM P2A, CSIRO) the role of remineralisation is dominant in generating this feature, indicated by a meridional increase in total, but not in preformed, phosphate concentrations.

Waters found in the Pacific Ocean originate both from the North Atlantic and from the Southern Ocean (Broecker et al., 1991). $\mathrm{PO}_{4}$ concentrations progressively increase from south to north due to remineralisation processes (Fig. 3a, WOA). Simulated total phosphate concentrations are highest in MPIOM-HAMOCC, om1p7-BLINGv0, UVIC2.8 and CSIRO, where phosphate concentrations exceed $3 \mathrm{mmol} \mathrm{m}^{-3}$ at intermediate depths (1000 to $2000 \mathrm{~m}$ ) from $20^{\circ} \mathrm{S}$ to $50^{\circ} \mathrm{N}$. These high concentrations are associated with a preformedto-total phosphate ratio of less than 0.5 (Fig. 3b). Simulated $\mathrm{PO}_{4}$ fields are dominated by the remineralised fraction in the om1p7-BLINGv0 over most of the Pacific Ocean. OPAPISCES and MOM-P2A do not display $\mathrm{PO}_{4}$ concentrations higher than $3 \mathrm{mmol} \mathrm{m}^{-3}$.

In the case of OPA-PISCES, remineralisation occurs at shallow depths and thus in regions where residence times are shorter, limiting the accumulation of regenerated phosphate. This shallow remineralisation could be due to too slow sinking speed or too fast remineralisation. Inversely in MPIOMHAMOCC, remineralisation occurs in deeper and older water, where preformed values are already high. The apparent non-conservative behavior of simulated preformed phosphate concentrations in MPIOM-HAMOCC and CCSM3 is an artefact that can be linked to high denitrification rates (see
Appendix), as only aerobic respiration has been taken in account in the computation of the regenerated phosphate pool.

Having described the main differences and similarities between simulated and observed basin-scale $\mathrm{PO}_{4}$ distributions, a quantitative measure of the respective model's fit to observations can, for example, be obtained by the absolute $L 1$ misfit (Kriest et al., 2010)

$$
L 1_{\mathrm{abs}}=\sum_{i} \sum_{j} \sum_{k}\left|\mathrm{PO}_{4 \text { Model }}-\mathrm{PO}_{4 \mathrm{Obs}}\right|
$$

where $\mathrm{PO}_{4 \text { Model }}$ and $\mathrm{PO}_{4 \mathrm{Obs}}$ are modeled and observed (WOA) phosphate concentrations and $i, j, k$ denote the dimensions of the spatial domain. The sums of the norm are weighted by the relative volume of the corresponding grid boxes $\frac{V_{i j k}}{V_{\text {total }}}$. Absolute $L 1$ norms are computed for total, preformed and regenerated $\mathrm{PO}_{4}$, respectively.

For the model configurations studied here, total $\mathrm{PO}_{4}$ misfits as well as misfits of the preformed and remineralised components are shown in Fig. 4. Absolute total $\mathrm{PO}_{4}$ misfits are generally smallest in the Southern Ocean, higher in the Pacific Ocean (Fig. 4c) and largest in the Atlantic Ocean (Fig. 4d). The different magnitudes of the misfits are correlated with the complexity of the composition of the different water masses in the different basins. For instance, the Southern Ocean presents a relatively simple vertical water mass structure, whereas the Atlantic ocean is characterised by different deep and intermediate waters. Any vertical misplacement of this structure by the models can generate high misfits in total phosphate. 
Several models display absolute misfits in total phosphate that are smaller than the individual misfits of preformed phosphate or regenerated phosphate, indicated by the symbols located to the left of the red lines in Fig. 4. This indicates some compensation of errors in preformed phosphate by errors in remineralised phosphate, e.g. by too low preformed phosphate concentrations being accompanied by too high concentrations of regenerated phosphate (and vice versa). A compensation is also suggested by the fact that models with large errors in preformed phosphate often display large errors in regenerated phosphate, as seen by the relatively close mirror symmetry of the different panels of Fig. 4 with respect to the horizontal zero line. If no compensation of errors in preformed and regenerated phosphate existed, and if total amounts of preformed and regenerated phosphate misfits were identical, the model solutions would lie on the green lines displayed in Fig. 4. This is not the case, and essentially all model solutions are located to the left of the green lines.

A compensation of errors in preformed and regenerated phosphate is largest in the Southern Ocean, where modeldata misfits of total phosphate are for most models smaller than total phosphate misfits in the Pacific or Atlantic Ocean as well as in the global average. Model-data misfits in both preformed and regenerated phosphate, in contrast, tend to be higher in the Southern Ocean than in the other ocean basins. This suggests that particularly in the Southern Ocean, a relatively good fit to observed total phosphate concentrations can be reached by a very unrealistic partitioning into preformed and regenerated phosphate. Given the close correlation of changes in preformed phosphate and atmospheric $\mathrm{CO}_{2} \mathrm{ob}-$ served for some models (Marinov et al., 2008), a model evaluation based on preformed (regenerated) rather than total phosphate concentrations may reveal more details about the quality of the model. In particular, Southern Ocean biogeochemistry is, in many models, not as well simulated as one might think when looking at simulated total $\mathrm{PO}_{4}$ distributions only.

Using the root-mean-square norm to measure model-data misfits yields very similar results (see Appendix Fig. A1). Also, a correction for denitrification impacts on the estimated regenerated phosphate (see Appendix) for the models including an explicit nitrogen cycle (MPIOM-HAMMOCC and CCSM3-BEC) does not change the results significantly as indicated by the yellow and purple symbols included in Fig. 4.

\section{Conclusions}

Using a set of state-of-the-art coupled biogeochemistrycirculation models of the global ocean, this study has shown that a good representation of annual mean phosphate distributions in the ocean does not automatically imply that also the preformed and regenerated phosphate components are reproduced at a similar level of accuracy. A realistic represen- tation of preformed and regenerated nutrient distributions is, however, relevant for assessing the sensitivity of marine biogeochemical cycles and marine $\mathrm{CO}_{2}$ uptake to environmental changes. The underlying notion is that preformed (regenerated) phosphate reflects the amount of phosphate returning to the ocean interior by physical (biological) processes.

The partitioning into preformed and regenerated phosphate has been based on the canonical AOU concept (Redfield et al., 1963; Weiss, 1970), which assumes that a subducted water mass is fully saturated with respect to atmospheric oxygen at its temperature and salinity values. However, in reality as well as in an ocean model, the degree to which surface saturation is reached before the water is transported away from the surface layer depends on several factors. These factors include the intensity of air-sea gas exchange (e.g. wind speed), cooling of surface water, entrainment of low-oxygen waters from deeper layers as well as in situ biological processes (respiration or production of oxygen). At high latitudes, ice-cover can further slow down airsea exchange. Namely the processes of cooling, ice-cover and entrainment act in the same direction and lead to an undersaturation of surface waters during winter at high latitudes when and where most of the water masses inhabiting the deep ocean are formed. High latitudes are sparsely sampled during the winter season (Koeve, 2001, 2006). However, winter-time undersaturation has been observed, for example in the Wedell Sea, one prominent region of deep water formation, of up to about $20 \%$ (Weiss et al., 1979; Gordon and Huber, 1990; Hopema et al., 1995; Russell and Dickson, 2003) and is in good agreement with a model study that applied an explicit tracer of preformed oxygen (Ito et al., 2004). Oxygen undersaturation in newly formed deep waters translates into an overestimation of oxygen use when the canonical AOU concept is applied, as recognized from early on (Redfield et al., 1963). The published observations and model studies available so far suggest that this bias, however, is comparable in models and the real ocean.

For doing better, two things are needed and likely will be available in the near future. First and most importantly, more unbiased winter time observations from high latitudes are required. Provided that current sensor calibration issues can be solved, our understanding of winter time oxygen saturation at high latitudes can be expected to improve considerably within a few years from now. In models, the skill of the AOU approach can be tested explicitly, following the methodology of Ito et al. (2004). However, computing the TOU requires the use of an explicit tracer for preformed oxygen. This tracer is fixed at the surface at every time step to the total oxygen concentration and then transported passively into the ocean interior without being subject to biotically induced fluxes. Experiment with such tracers, however, were not available for the models presented here.

Despite the limits of the canonical AOU concept, the use of regenerated and preformed phosphate pools in global scale "skill" metrics provides a diagnostic that is more sensitive to 

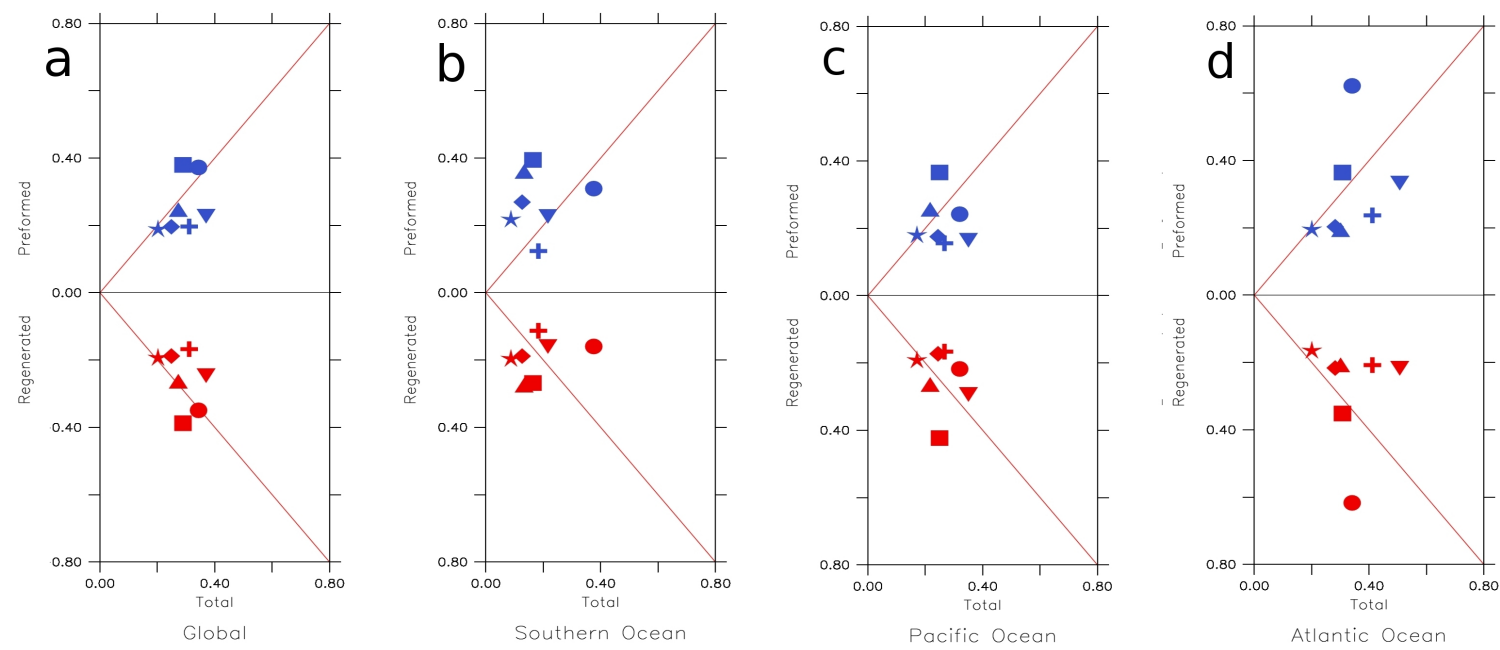

$\triangle$ OPA - PISCES

- MPIOM - HAMOCC

- CCSM3 - BEC

$\star$ UVIC

om1p7 - BLINGv0

+ CSIRO

$\checkmark$ MOM P2A

Fig. A1. Absolute misfits $\left(\mathrm{mmol} \mathrm{m}^{-3}\right)$ for regenerated, preformed (ordinate) and total phosphate (abscissa) in (a) global, (b) Southern Ocean, (c) Pacific and (d) Atlantic Ocean. Root square of the L2 absolute misfit has been used: $L 2$ abs $=\sum_{i} \sum_{j} \sum_{k}\left(\mathrm{PO}_{4 \mathrm{Model}}-\mathrm{PO}_{4 \mathrm{Obs}}\right)^{2}$.

differences in circulation and biology than metrics based on total phosphate alone.

For the models investigated here, it turned out that low (high) values of preformed tend to be compensated by high (low) values of remineralised phosphate, suggesting some corrections of deficiencies in the physics by a tuned biogeochemical model component. This indicates that models may fit observed phosphate distributions for the wrong reasons. For the models analyzed here, this is particularly the case in the Southern Ocean.

As a conclusion, we re-iterate the need of establishing a set of validation tools for biogeochemical models. In addition to the common inspection of total nutrient concentrations, we recommend considering also preformed and regenerated nutrient components. This comes at little additional cost, but can provide additional information about mechanisms responsible for the generation of biogeochemical tracer distributions. Using the concepts of preformed and regenerated nutrients, which reflect the interplay between marine biology and ocean circulation, should help to better constrain the ability of coupled biogeochemical models to reproduce the processes relevant for global biogeochemical tracer distributions.

\section{Appendix A}

\section{Estimated impact of denitrification on regenerated phosphate}

The denitrification process has been estimated in the computation of the regenerated phosphate pool. We assume that denitrification has occurred wherever there is a nitrate deficit with respect to the Redfield equivalent of total phosphate, computed as $\mathrm{NO}_{3}-16 \mathrm{PO}_{4}$. Remineralisation of $1 \mathrm{~mol}$
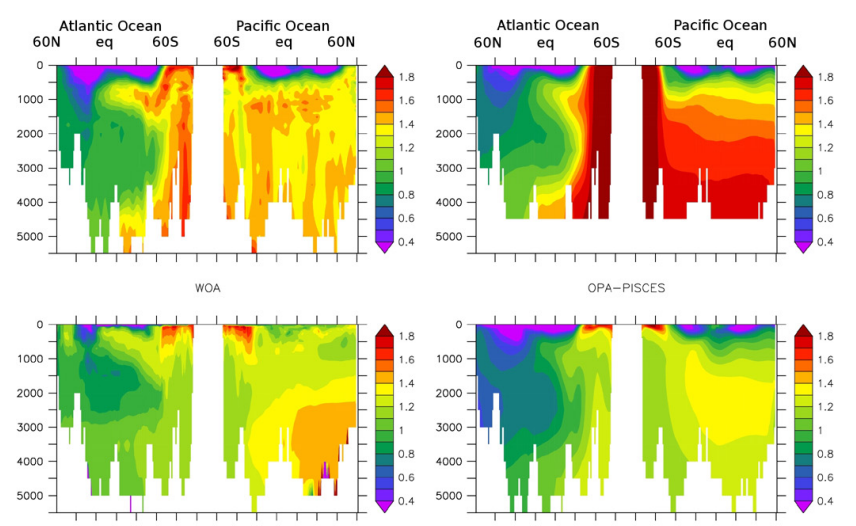

MPIOM-HAMOCC

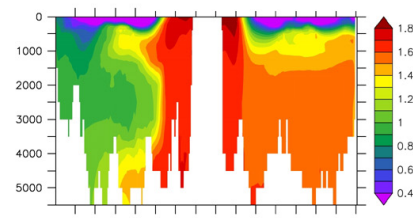

UVIC

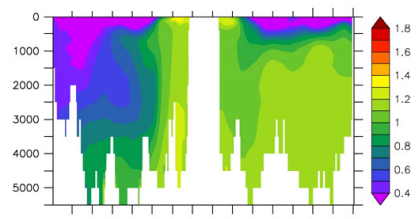

OM1P7-BLLNGro

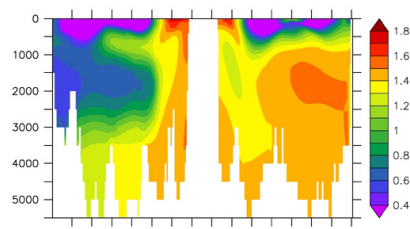

CSIRO

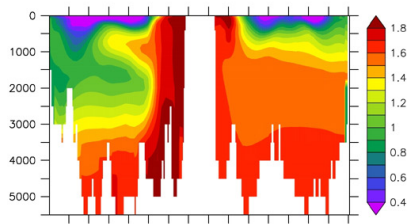

Mом P2A

Fig. A2. Preformed phosphate concentration $\left(\mathrm{mmol} \mathrm{m}^{-3}\right)$ taking into account the impact of denitrification along an Atlantic meridional section $\left(30^{\circ} \mathrm{W}\right)$ and a Pacific meridional section $\left(150^{\circ} \mathrm{W}\right)$ in different datasets: WOA, OPA-PISCES, MPIOM-HAMOCC, CCSM3-BEC, UVIC2.8, om1p7-BLINGv0, CSIRO, MOM P2A. 
of phosphate consumes $4 / 5 \cdot \operatorname{ratio}\left(-\mathrm{N} / \mathrm{O}_{2}\right)$ moles of nitrate (Paulmier et al., 2009). However, the limitation of this approach is the assumption that waters with $\mathrm{NO}_{3}-16 \mathrm{PO}_{4}>0$ have not experienced denitrification and that all denitrification leaves a trace in negative $\mathrm{NO}_{3}-16 \mathrm{PO}_{4}$. Applying this correction, preformed phosphate conservative properties are significantly improved in MPIOM-HAMOCC and CCSMBEC (Figs. 4 and A2). At basin scale, model-data differences computed following the rationale of Kriest et al. (2010) display slight improvements; however, the general picture is virtually unchanged (Fig. 4).

Acknowledgements. We acknowledge financial support to O.D. and A.O. from the Deutsche Forschungsgemeinschaft (SFB 754), to W.K. from the German Federal Ministry of Education and Research (FKZ 03F0608A, BIOACID), to E.G. from Compute Canada, to R.J.M. from the funding support of the Australian Climate Change Science Program and to J.S. from the EU FP7 project CARBOCHANGE (Grant no. 264879). The research of D.B. was supported by the Office of Science (BER), US Department of Energy, Award DE-FG02-07ER64467. The work of E.G. was supported in part by BP and Ford Motor Company through the Carbon Mitigation Initiative at Princeton University and under award NA17RJ2612 and NA08OAR4320752 from the National Oceanic and Atmospheric Administration, US Department of Commerce. The statements, findings, conclusions, and recommendations are those of the authors and do not necessarily reflect the views of the National Oceanic and Atmospheric Administration, or the US Department of Commerce.

Edited by: J. Middelburg

\section{References}

Anderson, L. and Sarmiento, J.: Redfield ratios of remineralization determined by nutrient data analysis, Global Biogeochem. Cy., 8, 65-80, 1994.

Aumont, O. and Bopp, L.: Globalizing results from ocean in situ iron fertilization studies, Global Biogeochem. Cy., 20, GB2017, doi:10.1029/2005GB002591, 2006.

Broecker, W. S. and Peng, T. H: Tracers in the Sea. New York: Eldigio press, 1982.

Broecker, W. S., Takahashi, T., and Takahashi, T. T.: Sources and flow patterns of deep ocean waters as deduced from potential temperature, salinity, and initial phosphate concentration. J. Geophys. Res., 90, 6295-6939, 1985.

Broecker, W., Blanton, S., Smethie Jr., W., and Ostlund, G.: Radiocarbon decay and oxygen utilization in the deep Atlantic Ocean, Global Biogeochem. Cy., 5, 87-117, 1991.

Codispoti, L. A., Brandes, J. A, Christensen, J. P., Devol, A. H., Naqvi, S. W. A., Paerl, H., W., and Yoshinari, T.: The oceanic fixed nitrogen and nitrous oxide budgets: Moving targets as we enter the anthropocene? Scientia Marina, 65 (Suppl. 2), 85-105, 2001.

Conkright, M. E, Gregg, W. W., and Levitus, S.: Seasonal cycle of phosphate in the open ocean, Deep-Sea Res. I, 47, 159-175, 2000 .
Friedlingstein, P., Cox, P., Betts, R., Bopp, L., Von Bloh, W., Brovkin, V., Cadule, P., Doney, S., Eby, M., Fung, I., Bala, G., John, J., Jones, C., Joos, F., Kato, T., Kawamiya, M., Knorr, W., Lindsay, K., Matthews, H., Raddatz, T., Rayner, P., Reick, C., Roeckner, E., Schnitzler, K., Schnur, R., Strassmann, K., Weaver, A., Yoshikawa, C., and Zeng, N.: Climate-carbon cycle feedback analysis: results from the C4MIP model intercomparison, J. Climate, 19, 3337-3353, 2006.

Galbraith, E. D., Gnanadesikan, A., Dunne, J. P., and Hiscock, M. R.: Regional impacts of iron-light colimitation in a global biogeochemical model, Biogeosciences, 7, 1043-1064, doi:10.5194/bg-7-1043-2010, 2010.

Garcia, H. E., Locarnini, R. A., Boyer, T. P., and Antonov, J. I.: World Ocean Atlas 2005, Vol. 3: Dissolved Oxygen, Apparent Oxygen Utilization, and Oxygen Saturation, edited by: Levitus, S., NOAA Atlas NESDIS 63, US Government Printing Office, Washington, D.C., 342 pp., 2006 a.

Garcia, H. E., Locarnini, R. A., Boyer, T. P., and Antonov, J. I.: World Ocean Atlas 2005, Vol. 4: Nutrients (Phosphate, Nitrate, Silicate), edited by: Levitus, S., NOAA Atlas NESDIS 64, US Government Printing Office, Washington, D.C., 396 pp., $2006 \mathrm{~b}$.

Gnanadesikan, A., Dunne, J., Key, R., Matsumoto, K., Sarmiento, J., Slater, R., and Swathi, P.: Oceanic ventilation and biogeochemical cycling: Understanding the physical mechanisms that produce realistic distributions of tracers and productivity, Global Biogeochem. Cy., 18, GB4010, doi:10.1029/2003GB002097, 2004.

Gordon, A. and Huber, B.: Southern ocean mixed layer, J. Geophys. Res.-Oceans, C7, 11655-11672, 1990.

Hoppema, M., Fahrbach, E., Schröder, M., Wisotzki, A., and De Baar, H. J. W.: Winter-summer differences of carbon dioxide and oxygen in the Weddell Sea surface layer, Mar. Chem., 51, 177192, 1995.

Ito, T. and Follows, M.: Preformed phosphate, soft tissue pump and atmospheric $\mathrm{CO}_{2}$, J. Mar. Res., 63, 813-839, 2005.

Ito, T., Follows, M., and Boyle, E.: Is AOU a good measure of respiration in the oceans?, Geophys. Res. Lett., 31, L17305, doi:10.1029/2004GL020900, 2004.

Koeve, W.: Wintertime nutrients in the North Atlantic - new approaches and implications for estimates of seasonal new production, Mar. Chem., 74, 245-260, 2001.

Koeve, W.: Stoichiometry of the biological pump in the North Atlantic - constraints from climatological data, Global Biogeochem. Cy., 20, GB3018, doi:10.1029/2004GB002407, 2006.

Koeve, W. and Kähler, P.: Heterotrophic denitrification vs. autotrophic anammox - quantifying collateral effects on the oceanic carbon cycle, Biogeosciences, 7, 2327-2337, doi:10.5194/bg-7-2327-2010, 2010.

Kortzinger, A., Hedges, J., and Quay, P.: Redfield ratios revisited: Removing the biasing effect of anthropogenic $\mathrm{CO}_{2}$, Limnol. Oceanogr., 46, 964-970, 2001.

Kriest, I., Khatiwala, S., and Oschlies, A.: Assessment of simple global marine biogeochemical models of increasing complexity, Prog. Oceanogr., 86, 336-360, 2010.

Krishnamurthy, A., Moore, J., Mahowald, N., Luo, C., Doney, S., Lindsay, K., and Zender, C.: Impacts of increasing anthropogenic soluble iron and nitrogen deposition on ocean biogeochemistry, Global Biogrochem. Cy., 23, GB3016, doi:10.1029/2008GB003440, 2009. 
Li, Y. H., Karl, D. M., Winn, C. D., Mackenzie, F. T., and Gans, K.: Remineralization ratios in the subtropical north Pacific gyre, Aquatic Geochem., 6, 65-86, 2000.

Maier-Reimer, E.: Geochemical cycles in an ocean general circulation model: preindustrial tracer distributions, Global Biogeochem. Сy., 7, 645-677, 1993.

Maier-Reimer, E., Kriest, I., Segschneider, J., Wetzel, P.: The Hamburg Ocean Carbon Cycle Model HAMOCC5.1 - Technical Description Release 1.1 - Berichte zur Erdsystemforschung 14/2005, Max-Planck-Institut für Meteorologie, Hamburg, Germany, available at: http://www.mpimet.mpg.de/wissenschaft/ publikationen/berichteerdsystemforschung.html, last access: December 2011, 2005.

Marinov, I., Gnanadesikan, A., Sarmiento, J., Toggweiler, J., Follows, M., and Mignone, B.: Impact of oceanic circulation on biological carbon storage in the ocean and atmospheric $p \mathrm{CO}_{2}$, Global Biogeochem. Cy., 22, GB3007, doi:10.1029/2007GB002958, 2008.

Matear, R. and Hirst, A.: Long-term changes in dissolved oxygen concentrations in the ocean caused by protracted global warming, Global Biogeochem. Cy., 17, 1125, doi:10.1029/2002GB001997, 2003.

Najjar, R., Jin, X., Louanchi, F., Aumont, O., Caldeira, K., Doney, S., Dutay, J., Follows, M., Gruber, N., Joos, F., Lindsay, K., Maier-Reimer, E., Matear, R., Matsumoto, K., Monfray, P., Mouchet, A., Orr, J., Plattner, G., Sarmiento, J., Schlitzer, R., Slater, R., Weirig, M., Yamanaka, Y., and Yool, A.: Impact of circulation on export production, dissolved organic matter, and dissolved oxygen in the ocean: Results from phase II of the Ocean Carbon-cycle Model Intercomparison Project (OCMIP-2), Global Biogeochem. Cy., 21, GB3007, doi:10.1029/2006GB002857, 2007.

Oschlies, A., Schulz, K., Riebesell, U., and Schmittner, A.: Simulated 21 st century's increase in oceanic suboxia by $\mathrm{CO}_{2}$ enhanced biotic carbon export, Global Biogeochem. Cy., 22, GB4008, doi:10.1029/2007GB003147, 2008.
Paulmier, A., Kriest, I., and Oschlies, A.: Stoichiometries of remineralisation and denitrification in global biogeochemical ocean models, Biogeosciences, 6, 923-935, doi:10.5194/bg-6923-2009, 2009.

Redfield, A. C., Ketchum, B. H., and Richards, F. A.: The influence of organisms on the composition of seawater, in: The Sea, vol. 2, edited by: Hill, M. N., John Wiley and Sons, New York, 26-77, 1963.

Roy, T., Bopp, L., Gehlen, M., Schneider, B., Cadule, P., Frolicher, T., Segschneider, J., Tjiputra, J., Heinze, C., and Joos, F.: Regional impacts of climate change and atmospheric $\mathrm{CO}_{2}$ on future ocean carbon uptake: a multimodel linear feedback analysis, J. Climate, 24, 2300-2318, 2011.

Russell, J. L. and Dickson, A. G.: Variability in oxygen and nutrients in South Pacific Antarctic intermediate water, Global Biogeochem. Cy., 17, 1033, doi:10.1029/2000GB001317, 2003.

Schlitzer, R. : Carbon export fluxes in the Southern Ocean: results from inverse modelling and comparison with satellite-based estimates, Deep Sea Res. II, 49, 1623-1644, 2002.

Schneider, B., Bopp, L., Gehlen, M., Segschneider, J., Frölicher, T. L., Cadule, P., Friedlingstein, P., Doney, S. C., Behrenfeld, M. J., and Joos, F.: Climate-induced interannual variability of marine primary and export production in three global coupled climate carbon cycle models, Biogeosciences, 5, 597-614, doi:10.5194/bg-5-597-2008, 2008.

Takahashi, T., Broecker, W. S., and Langer, S.: Redfield ratio based on chemical data from isopycnal surfaces, J. Geophys. Res.Oceans, C4, 6907-6924, 1985.

Weiss, R.: The solubility of nitrogen, oxygen, and argon in water and seawater, Deep Sea Res., 17, 721-756, 1970.

Weiss R. F., Ostlund, H. G., and Craig, H.: Geochemical studies of the Weddell sea, Deep Sea Res. Pt. I, 26, 1093-1120, 1979. 